\title{
Arctic Quaternary Ostracods and Their Use in Paleoreconstructions
}

\author{
A. Yu. Stepanova ${ }^{a}$, E. E. Taldenkova ${ }^{b}$, and H. A. Bauch ${ }^{c}$ \\ ${ }^{a}$ Borissiak Paleontological Institute, Russian Academy of Sciences, Profsoyuznaya ul. 123, Moscow, 117997 Russia \\ e-mail: a.yu.stepanova@gmail.com \\ ${ }^{b}$ Geographical Faculty, Lomonosov Moscow State University, Moscow, 119899 Russia \\ ${ }^{c}$ Mainz Academy for Science, Humanities and Literature, c/o IFM-GEOMAR, Wischhofstrasse, 1-3, 24148 Kiel, Germany
}

Received May 15, 2008

\begin{abstract}
The paper deals with original and published data on fossil ostracodal assemblages from the Eurasian Arctic Kara, Laptev and Chuckchi seas. As a whole, six ecologically different assemblages were distinguished (freshwater, brackish water, marine of the inner, middle and outer shelves and upper continental slope), they replace each other upcore reflecting a gradual increase in water depth and distance from the coast. These assemblages are stable in the entire Arctic region and can be used for interpretation of environments in different Arctic areas.
\end{abstract}

Key words: Arctic, Quaternary, ostracods, paleoreconstructions.

DOI: $10.1134 / \mathrm{S} 0031030110010065$

\section{INTRODUCTION}

Recent ostracods from the Arctic seas and adjacent high latitude regions are studied relatively well. The first publications on their taxonomy came out by the end of the 19th century and represented short descriptions and illustrations of ostracods mostly from the western European Arctic. Within the last 40 years many detailed taxonomic papers with descriptions and scanning micrographs of recent ostracods were published (Neale and Howe, 1975; Whatley and Masson, 1979; Whatley and Coles, 1987; Athersuch et al., 1989; Brouwers, 1990, 1993, 1994; Whatley et al., 1996, 1998; Stepanova et al., 2003, 2004, 2007; Stepanova, 2006) as well as the databases on the distribution of recent Arctic ostracods (Cronin et al., 1991; Shornikov, 2001, 2004). These works contain precise information on the depth, salinity, and temperature of the environments inhabited by different ostracod species and thus can be used for paleoenvironmental reconstructions. The ostracod faunas of the Barents, Kara, and Laptev seas, Gulf of Alaska, Beaufort Sea, and the coastal waters of Great Britain and eastern Greenland are the best studied ones.

The fossil Quaternary ostracods have been studied less. The first fragmentary data on Tertiary ostracods from England and Scotland only contained descriptions and illustrations of carapaces (Jones, 1857; Brady, 1865; Brady and Crosskey, 1871; Brady et al., 1874). While analyses of the taxonomic composition of the ostracod assemblages were first published only in the second half of the twentieth century, the gradual accumulation of data on recent material made it pos- sible not only to describe but also to interpret these assemblages.

Some of the most detailed reconstructions are of particular importance. In one of the first papers devoted to the Pleistocene ostracods from the Gubik Formation, Alaska, F. Swain (1963) identified freshwater and marine sediments based on the composition of ostracod assemblages and distinguished between purely marine and brackish-water ostracods. O. Lev $(1972,1983)$ analyzed in detail ostracod assemblages from the Neogene-Quaternary deposits of the Malaya Zemlya tundra, Western Siberian Lowland, Arctic islands, Taimyr Peninsula, and northern part of the Gulf of Anadyr and described ostracod assemblages that can be used for stratigraphic correlation of deposits from different regions. She subdivided ostracods in three groups according to the salinity tolerance range (euhaline (30-40), brachyhaline (18-30), pliohaline $(10-18))$ and in four groups according to their temperature preference (arctic, subarctic, moderately cold-water, moderately warm-water). T. Cronin (1977, 1981, 1989) studied and interpreted ostracod assemblages from the Champlain Sea (Gulf of St. Lawrence). He described different ostracod assemblages and gave their ecological interpretation. Special attention was paid to the significance of ostracods in paleoreconstructions of shallow marine environments. Cronin distinguished climatic stages according to different locations of ice sheet margins and inundation levels of the St. Lawrence Lowlands. Ostracods were classified according to their specific salinity and temperature range. K. McDougall et al. (1986) gave a 


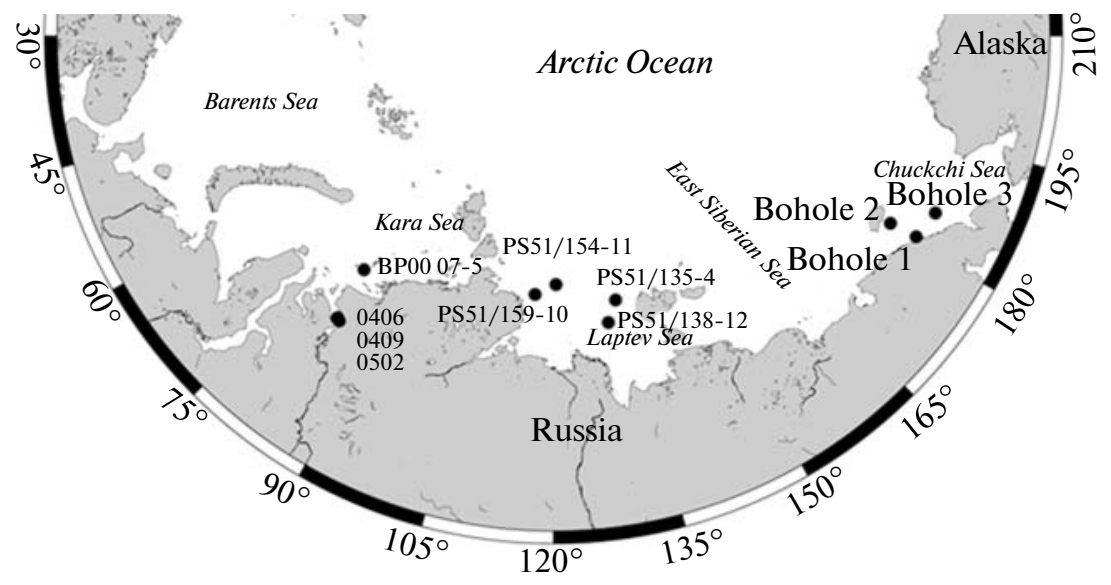

Fig. 1. Schematic map of the studied sections.

detailed description of shallow-water PleistoceneHolocene ostracod assemblages from seven drill cores in the Beaufort Sea. The Pelukian (Marine Isotope Stage (MIS) 5e), Simpsonian (MIS 5a and 5c) and Flandrian (Holocene) transgressions were characterized by different ostracod assemblages indicating various depth, temperature, salinity, and hydrological regime.

Papers on the North Sea (Woszidlo, 1962; Lord, 1980, 1993; Penney, 1990; Ingram, 1998), Pechora Sea (Kupriyanova, 1999), Fram Strait (Mostafawi, 1990), Gulf of Alaska (Brouwers, 1988), and Beaufort Sea (Siddiqui and Milne, 1990) are less detailed but are also of great importance.

The preciseness of the interpretation depends on the availability of the ecological data on identified ostracod species and purposes and tasks of each particular study. When grouping species researches usually only use parameters critical for a particular studied environment. In our study of the Kara and Laptev seas ostracods, we only considered environmental changes in depth and salinity and thus subdivided species accordingly, as bottom water temperature does not fluctuate a lot within the studied time interval (last 17 cal.kyrs), additionally we distinguished North Atlantic taxa (Stepanova, 2006). In the waters of Western Europe and North America distribution of ostracod species is linked to bottom temperatures distribution or bottom vegetation (e.g., Lord, 1980; Cronin, 1989). Ostracods may as well be used for reconstructions of paleosalinity, depth, temperature, type of sediment and algae, and degree of water pollution.

\section{MATERIAL}

We studied coastal outcrops and shelf cores of Arctic Eurasia from the Kara Sea to the Chuckchi Sea
(Fig. 1). All studied samples were of PleistoceneHolocene age and reflect the transition from estuarine to marine environment.

Marine core sections from the Laptev Sea were obtained in 1998 during the expedition TRANSDRIFT V onboard the R/V Polarstern. Three cores from the Laptev Sea shelf are located in the paleovalleys of the biggest rivers of the region. Core PS51/13812 from the eastern shelf is $5.3 \mathrm{~m}$ long and was collected in the Lena paleovalley $\left(130^{\circ} 88.2 \mathrm{E}, 75^{\circ} 12.3 \mathrm{~N}\right.$, water depth $45 \mathrm{~m}$ ). Core PS51/135-4 is $5.6 \mathrm{~m}$ long and was obtained in the paleovalley of the Yana River $\left(133^{\circ} 24.3 \mathrm{E} ; 76^{\circ} 16.5 \mathrm{~N}\right.$, water depth $\left.51 \mathrm{~m}\right)$. Core PS51/159-10 is $4.6 \mathrm{~m}$ long and comes from the western shelf of the Laptev Sea from the Khatanga paleovalley $\left(116^{\circ} 03.2 \mathrm{E} ; 76^{\circ} 76.7 \mathrm{~N}\right.$, water depth $\left.60 \mathrm{~m}\right)$. Core PS51/154-11 is $7 \mathrm{~m}$ long and was collected on the western continental slope $\left(120^{\circ} 61.0 \mathrm{E} ; 7^{\circ} 28.6 \mathrm{~N}\right.$, water depth $270 \mathrm{~m}$ ) (Fig. 1).

Core BP00/07-5 was collected during the expedition SIRRO-2000 onboard the R/V Akademik Boris Petrov from the eastern Kara Sea shelf. The core is $6.3 \mathrm{~m}$ long and was collected in the topographic depression, the paleoestuary of the Yenisei River $\left(81.1^{\circ} \mathrm{E}, 74.7^{\circ} \mathrm{N}\right.$, water depth $\left.43 \mathrm{~m}\right)$ (Fig. 1).

Chronology of all cores of the Kara and Laptev seas is based on the radiocarbon dates (AMS) of marine biogenic calcite of bivalves, ostracods, and foraminifers (Bauch et al., 2001; Taldenkova et al., 2005; Simstich et al., 2004).

Research group from VNIIOkeangeologia (Gusev et al., 2005) collected samples from the coastal sections of the Yenisei River (outcrops from the right bank of Yenisei and east coast of the Gulf of Yenisei) during field campaigns of 2004-2005. We found ostracods at three stations: no. $0406\left(71^{\circ} 52.67^{\prime} \mathrm{E}, 83^{\circ} 8.82^{\prime} \mathrm{N}, 60 \mathrm{~m}\right.$ above sea level), no. 0409 ( $71^{\circ} 56.43^{\prime} \mathrm{E}, 82^{\circ} 37.99^{\prime} \mathrm{N}$, 
$79 \mathrm{~m}$ above sea level), and no. 0502 (71 ${ }^{\circ} 58.33^{\prime}$ E., $82^{\circ} 36.63^{\prime} \mathrm{N}, 82 \mathrm{~m}$ above sea level) (Fig. 1). Age of sediments was determined by the thermoluminescent analysis, spore-and-pollen and malacological analyses were also conducted (Streletskaya et al., 2007); some samples were studied for diatoms.

Three drill cores were collected by scientific researches from VNIIOkeangeologia in 2006 (Gusev et al., 2007) during the scientific cruise onboard tugboat Shuya in the Chuckchi Sea: no. 1 near the Cape of Schmidt, $5.5 \mathrm{~m}$ long $\left(179^{\circ} 19.2^{\prime} \mathrm{E}\right.$; 69 $0.53^{\prime} \mathrm{N}$, water depth $37 \mathrm{~m}$ ); no. 2 near the southern extremity of Wrangel Island, $12 \mathrm{~m}$ long $\left(179^{\circ} 23.72^{\prime} \mathrm{E}\right.$; 70³3.05' $\mathrm{N}$, water depth $39 \mathrm{~m}$ ); no. 3 from the southern Chuckchi Sea, $3.5 \mathrm{~m}$ long $\left(175^{\circ} 17.19^{\prime} \mathrm{E}\right.$; $68^{\circ} 47.8^{\prime} \mathrm{N}$, water depth $50 \mathrm{~m}$ ) (Fig. 1). The age of sediments was determined by the paleomagnetic and paleontological methods (spore-and-pollen, diatom, and foraminiferal analyses), and several radiocarbon dates were also date obtained (Gusev et al., 2007).

\section{RESULTS}

All paleoreconstructions are based on the occurrence of recent ostracods in sediments. We used published data on the distribution of ostracods in the Arctic seas, Western Europe, and the Arctic Ocean (Cronin et al., 1991; Shornikov, 2001, 2004, etc.) and our own database on ostracods in the Kara and Laptev seas (Stepanova et al., 2003, 2007; Stepanova, 2006). All Pleistocene-Holocene species studied are known from modern seas; depth and salinity ranges can be determined for most of them. Some species are restricted to a certain habitat, e.g., transformed Atlantic waters. Large quantity of the accumulated data allows us to interpret even poor fossil assemblages (Table 1).

1. The freshwater assemblage was distinguished in samples from the coastal outcrops of the Gulf of Yenisei. The assemblage is identical to the recent assemblage from this area (Stepanova et al., 2007). A similar assemblage was identified from the Late Pleistocene deposits of the western Chuckchi Sea shelf. In both cases purely freshwater composition of assemblage implies isolated continental conditions (lake, lagoon) (Table 1).

2. Brackish-water estuarine assemblage was distinguished in all shelf cores from the Laptev Sea. This environment existed during the initial stage of the Holocene transgression and flooding of the shelf, when the sites studied were located closer to the coast. The brackish-water assemblage of the modern $\mathrm{Ob}$ and Yenisei estuaries contains only two brackish-water species which agrees with the general rule of the taxonomic composition decrease under unstable conditions. Except the oldest samples from the cores from the Laptev Sea, the fossil estuarine assemblage is much richer. It implies that sampling sites were located near the shelf break that provided closer interaction with the waters of the open sea.

A similar assemblage was distinguished in the late Pleistocene deposits of the Chuckchi Sea. It is taxonomically poor but contains shallow-water marine, euryhaline, and brackish-water species, another evidence of a gradual transition to marine conditions.

\section{The marine inner shelf assemblage was identified} from the shelf cores in the Laptev and Kara seas where it replaces the estuarine assemblage following the sea level rise and coastline retreat during the Holocene transgression. It is similar to the recent inner shelf assemblage of these seas (Stepanova et al., 2007).

A similar assemblage was distinguished in the Holocene deposits of the Chuckchi Sea (Table 1). Though it is taxonomically poor, its ecological interpretation is reliable. Two species were identified from two samples: marine shallow-water and brackishwater ones. The marine species Acanthocythereis dunelmensis (Norman, 1865) corresponds to the inner-outer shelf environment and brackish-water Pteroloxa cumuloidea Swain, 1963 is known from the estuarine brackish-water environments but was also reported from the inner shelf. Thus we consider the ecological conditions to be brackish-water.

4. The marine assemblage of the middle shelf was distinguished in the entire area studied. In the Kara and Laptev seas it replaces marine inner shelf assemblage as the coastline moves southwards and marine conditions stabilize on the shelf (Table 1). This assemblage is similar to the recent ostracod assemblage from this area (Stepanova et al., 2007). It is the youngest fossil assemblage in the eastern part of the Laptev Sea since the conditions on the middle shelf stabilized after the sea level reached modern value at around five to six thousand years ago (Bauch et al., 1999, 2001).

The Chuckchi Sea sediments encompass analogous Holocene marine assemblages of the middle shelf. In borehole no. 2 this assemblage follows the Late Pleistocene assemblage of the inner shelf and in borehole no. 1 it is the youngest Holocene assemblage.

Some assemblages contain both true shallow- and deep-water species dwelling on the outer shelf and upper continental slope. We refer such assemblages to as the transitional middle-outer shelf assemblages. Similar assemblage was recorded in the coastal outcrops of the Yenisei where typical shallow marine species co-occurred with relatively deep-water marine taxa: Sarsicytheridea punctillata (Brady, 1865), Cluthia cluthae (Brady, Crosskey et Robertson, 1874), and Elofsonella concinna (Jones, 1857).

5. Marine outer shelf assemblage was recovered in the sections from the Laptev, Kara, and Chuckchi 


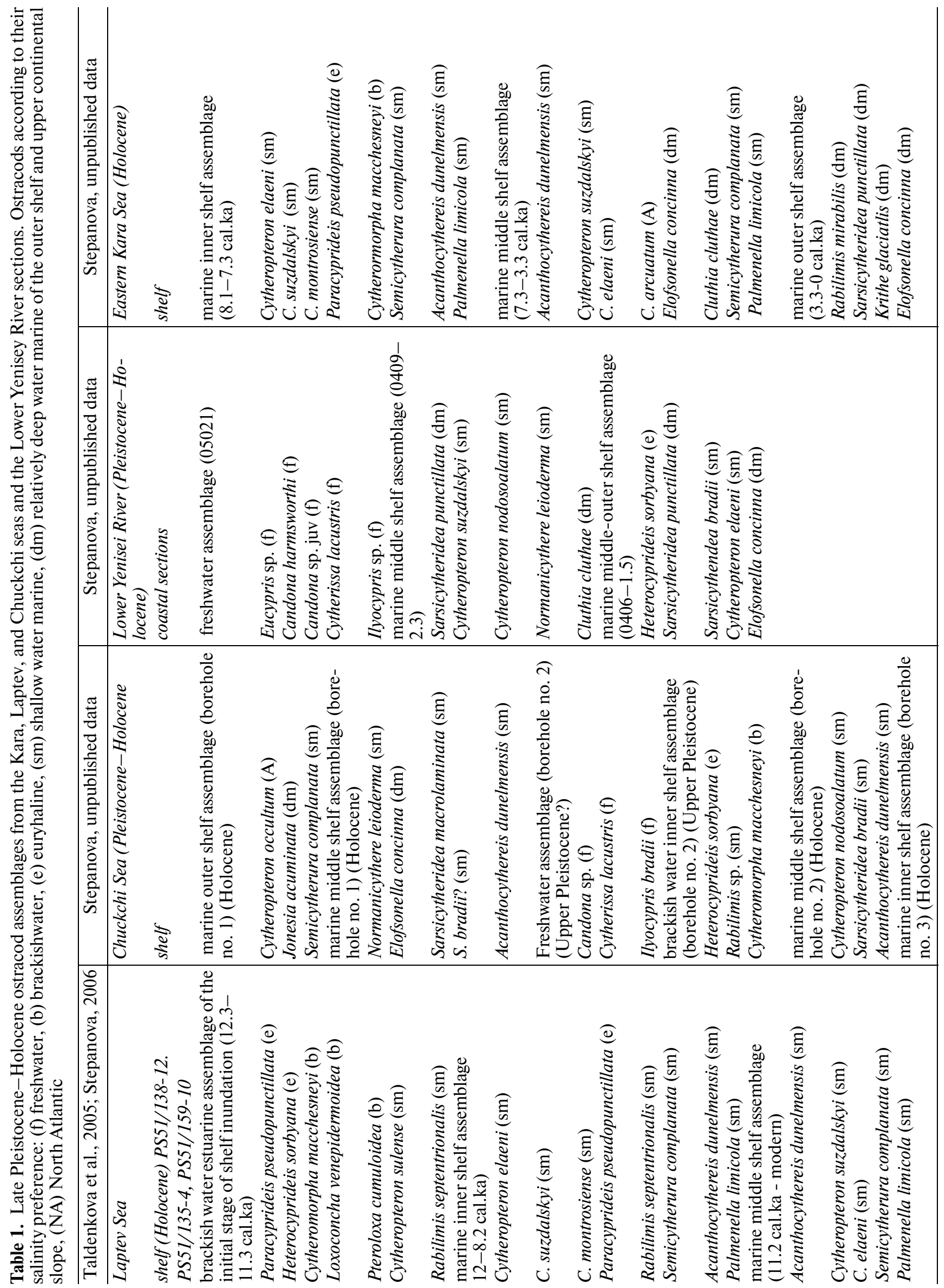

PALEONTOLOGICAL JOURNAL Vol. $44 \quad$ No. 12010 


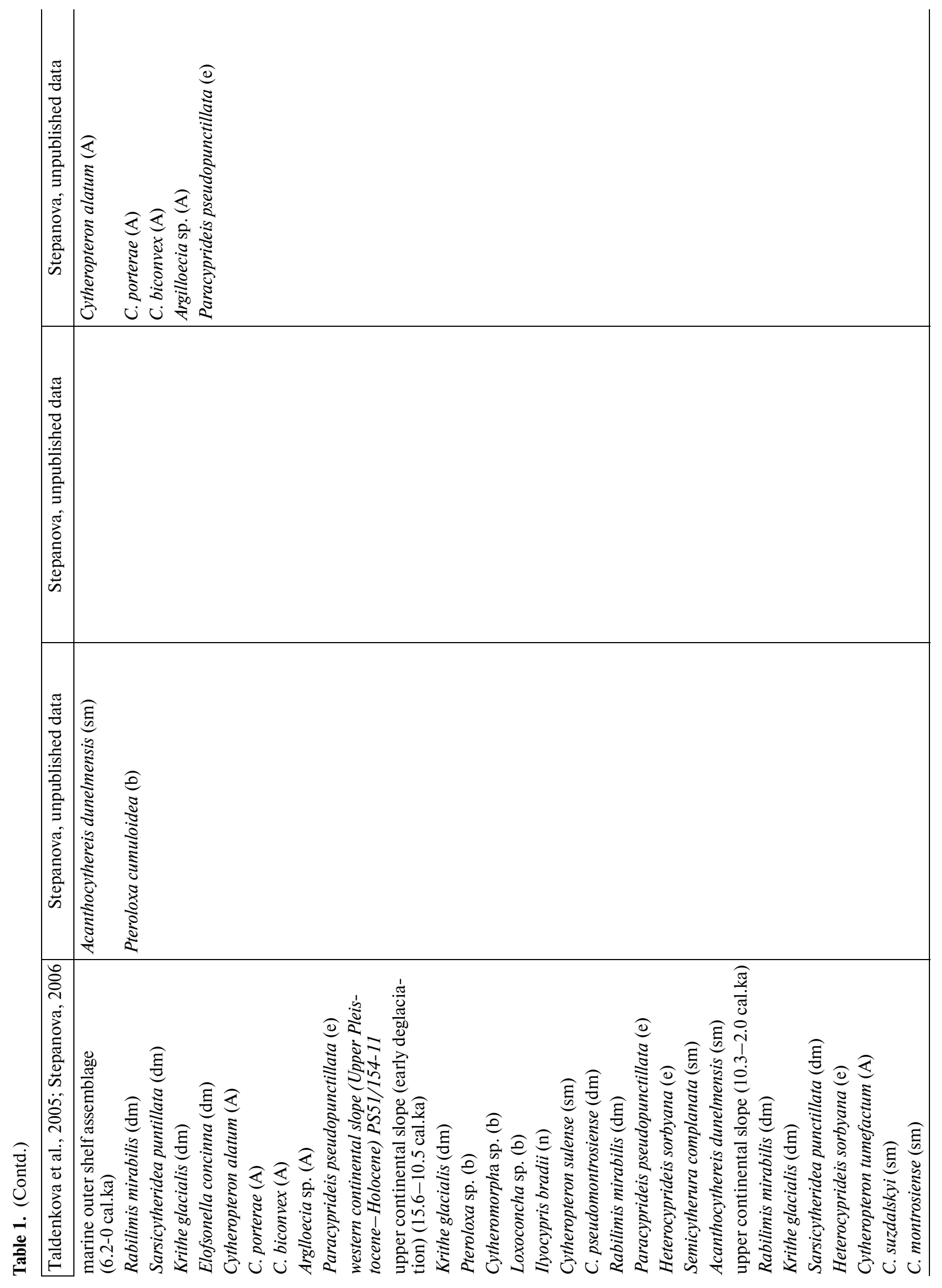

PALEONTOLOGICAL JOURNAL Vol. 44 No. 12010 
seas. These assemblages are composed mostly of deepwater species and also contain North Atlantic taxa that inhabit the continental slope and may also penetrate onto the shelf with the reversed currents. This is the youngest assemblage in the shelf cores from the western Laptev Sea and eastern Kara Sea. Assemblage 5 is similar to the recent ostracod assemblage from these seas (Stepanova et al., 2007).

6. Marine assemblage of the upper continental slope was distinguished only in the core from the western continental slope of the Laptev Sea. This assemblage contains mostly deep sea, North Atlantic and some shallow-water species. The latter were ice-rafted from the shallow shelf area. In the surface sediments the shallow-water species were also found on the outer shelf. The Late Pleistocene sediments of this section also contain brackish-water and freshwater species, the fact that is explained by active hydrodynamics and catastrophic events (landslides) during the period of deglaciation.

\section{CONCLUSIONS}

To summarize, we can conclude that accumulation of the data on the ecology of Arctic ostracod species was critical for reliable paleoenvironmental reconstructions.

Fossil Quaternary ostracod assemblages may be used for interpretation of ecological paleoenvironments as they can be compared to modern analogues and thus become very sensitive indicators of past environments. The range of water depth and salinity can be determined for most of Arctic ostracod species from the data on their occurrence in modern sediments, which makes it possible to interpret even taxonomically poor samples.

We distinguish six assemblages and their succession corresponds to the gradual water depth increase and southward coastline retreat: the freshwater, brackishwater estuarine, marine of the inner, middle and, outer shelves, and upper continental slope. Each assemblage is characterized by its own group of index species.

Arctic ostracod assemblages have a wide geographical stability and reflect the evolution of regional environments. The fossil assemblages from the Kara and Laptev seas shelf sediments reflect the transition from the coastal estuarine environments to the normal marine in the course of the Postglacial transgression. In the core from the continental slope they mark periods of enhanced influence of transformed Atlantic waters, glacial melt-water and river-water inflows, and periodical catastrophic events of the early deglaciation. Samples from the coastal sections from the Gulf of Yenisei and western Chuckchi Sea shelf are less representative but also indicative of the environments and document certain local environmental changes (boreholes nos. 1 and 2 in the Chuckchi Sea).

Interpretations of the distinguished fossil assemblages should be based on their modern analogs (Stepanova et al., 2007). To improve the accuracy of reconstructions it is necessary to continue collecting and analyzing the data on the distribution of ostracod species in different environments.

\section{ACKNOWLEDGMENTS}

This study was supported by the Russian Foundation for Basic Research, project no. 08-05-00849.

\section{REFERENCES}

1. J. Athersuch, D. J. Horne, and J. E. Whittaker, Marine and Brackish Water Ostracods, Ed. by J. Athersuch, D. J. Horne, and J. E. Whittaker (Linn. Soc. London, Leiden, 1989).

2. H. A. Bauch, H. Kassens, H. Erlenkeuser, et al., "Depositional Environment of the Laptev Sea (Arctic Siberia) during the Holocene," Boreas 28 (1), 201-204 (1999).

3. H. A. Bauch, T. Mueller-Lupp, E. Taldenkova, et al., "Chronology of the Holocene Transgression at the North Siberian Margin," Global and Planetary Change 31, 125-139 (2001).

4. G. S. Brady, "On Undescribed Fossil Entomostraca from the Brickearth of the Nar," Ann. Mag. Nat. Hist., Ser. 3, No. 16, 189-191 (1865).

5. G. S. Brady and H. W. Crosskey, "Notes on Fossil Ostracoda from the Post-Tertiary Deposits of Canada and New England," Geol. Mag. 8, 60-65 (1871).

6. G. S. Brady, H. W. Crosskey, and D. Robertson, "A Monograph of the Post-Tertiary Entomostraca of Scotland, Including Species from England and Ireland," Palaeontogr. Soc. London 28, 1-232 (1874).

7. E. M. Brouwers, "Palaeobathymetry on the Continental Shelf Based on Examples Using Ostracods from the Gulf of Alaska," in Ostracoda in the Earth Sciences (Elsevier, Amsterdam, 1988), pp. 55-77.

8. E. M. Brouwers, "Systematic Paleontology of Quaternary Ostracode Assemblages from the Gulf of Alaska: Part 1. Families Cytherellidae, Bairdiidae, Cytheridae, Leptocytheridae, Limnocytheridae, Eucytheridae, Krithidae, Cushmanideidae," U.S. Geol. Surv. Prof. Pap., No. 1510, 1-40 (1990).

9. E. M. Brouwers, "Systematic Paleontology of Quaternary Ostracode Assemblages from the Gulf of Alaska: Part 2. Families Trachyleberididae, Hemicytheridae, Loxoconchidae, Paracytheridae," U.S. Geol. Surv. Prof. Pap., No. 1531, 1-40 (1993).

10. E. M. Brouwers, "Systematic Paleontology of Quaternary Ostracode Assemblages from the Gulf of Alaska: Part 3. Family Cytheruridae," U.S. Geol. Surv. Prof. Pap., No. 1544, 1-43 (1994). 
11. T. M. Cronin, "Champlainian Sea Foraminifera and Ostracoda: A Systematic and Paleontological Synthesis," Geogr. Phys. Quat. 31 (1-2), 107-122 (1977).

12. T. M. Cronin, "Paleoclimatic Implications of Late Pleistocene Marine Ostracods from the St. Lawrence Lowlands," Micropaleontology 27 (4), 384-418 (1981).

13. T. M. Cronin, "Paleozoogeography of Postglacial Ostracoda from Northeastern North America: The Late Quaternary Development of the Champlainian Sea Basin," Geol. Assoc. Can. Spec. Pap., No. 35, 125-144 (1989).

14. T. M. Cronin, W. M. Briggs, Jr., E. M. Brouwers, et al., "Modern Arctic Podocopid Database," in USGS OpenFile Report (1991), pp. 91-385.

15. E. A. Gusev, Account of the Fieldwork in the Yenisei Mouth Region in 2005 (Min-vo Prirodn. Resur. RF Vseross. Nauchno-Issled. Inst. Geol. Mineral. Resur. Mirov. Okeana (VNIIOkeangeologiya), 2005) [in Russian].

16. E. A. Gusev, V. V. Popov, A. G. Iosifidi, et al., "The Structure of the Upper Cenozoic Sedimentary Cover of the Arctic Shelf of Chukotka," in Fundamental Problems in Studying the Quaternary Period: Proceedings V All-Russia Conference on the Study of the Quaternary Period (GEOS, Moscow, 2007), pp. 93-97 [in Russian].

17. C. Ingram, "Palaeoecology and Geochemistry of Shallow Marine Ostracoda from the Sand Hole Formation, Inner Silver Pit, Southern North Sea," Quatern. Sci. Rev. 17, 913-929 (1998).

18. T. R. Jones, A Monograph of the Tertiary Entomostraca of England (Palaeontogr. Soc. London, London, 1857), pp. 1-68.

19. N. V. Kupriyanova, "Biostratigraphy of Upper Cenozoic Sediment of the Pechora Sea by Ostracods," Ber. Polarforsch. 306, 62-79 (1999).

20. O. M. Lev, "Bionomic and Paleogeographic Conditions in the Neogene-Quaternary Marine Basins in the Northern Part of the USSR Based on the Ostracode Fauna," in The Modern Tectonics and Paleogeography of the Soviet Arctic in the Context of the Estimation of Mineral Resources (Nauchno-Issled. Inst. Geol. Arktiki, Leningrad, 1972), pp. 15-21 [in Russian].

21. O. M. Lev, "Neogene-Quaternary Ostracode Assemblages," in The Main Problems of the Late Cenozoic of the Arctic (Nedra, St. Petersburg, 1983), pp. 104-143 [in Russian].

22. A. Lord, "Weichselian (Late Quaternary) Ostracods from the Sandnes Clay, Norway," Geol. Mag. 117 (3), 227-242 (1980).

23. A. Lord, J. E. Robinson, and S. G. Moutzourides, "Ostracoda from Holstenian Deposits in the Hamburg Area," Geol. J. 138, 127-145 (1993).

24. K. McDougall, E. M. Brouwers, and P. Smith, "Micropaleontology and Sedimentology of the PB Borehole Series, Prudhoe Bay, Alaska," U.S. Geol. Surv. Bull., No. 1598, 1-62 (1986).
25. N. Mostafawi, "Ostracods in Late Pleistocene and Holocene Sediments from the Fram Strait, Eastern Arctic," in Ostracoda and Global Events, Ed. by R. C. Whatley and C. L. Maybury (Chapman and Hall, London, 1990), pp. 489-494.

26. J. W. Neale and H. V. Howe, "The Marine Ostracoda of Russian Harbour, Novaya Zemlya, and Other High Latitude Faunas," Bull. Am. Paleontol. 65 (282), 381-431 (1975).

27. D. N. Penney, "Quaternary Ostracod Chronology of the Central North Sea: The Record from BH 81/29," Cour. Forsch.-Inst. Senckenberg 123, 97-109 (1990).

28. E. I. Shornikov, "Class Ostracoda, Orders Platycopida and Podocopida," in Investigations of the Fauna of Seas, Vol. 51 (59): The List of Free-Living Invertebrate Species of the Eurasian Seas and Adjacent Deepwater Areas of the Arctic Ocean, Ed. by B. I. Sirenko (Zool. Inst. Ross. Akad. Nauk, St. Petersburg, 2001), pp. 99-103 [in Russian].

29. E. I. Shornikov, "The Fauna of Benthic Ostracodes (Crustacea, Ostracoda) of the Laptev Sea," in Investigations of the Fauna of Seas (Zool. Inst. Ross. Akad. Nauk, St. Petersburg, 2004), Vol. 54 (62), pp. 58-70 [in Russian].

30. Q. Siddiqui and J. Milne, "The Paleoecology of Ostracoda in Late Pleistocene Sediments from Borehole 85 GSC 1 in the Western Beaufort Sea," in Ostracoda and Global Events, Ed. by R.C. Whatley and C.L. Maybury (Chapman and Hall, London, 1990), pp. 495-503.

31. J. Simstich, V. Stanovoy, D. Bauch, et al., "Holocene Variability of Bottom Water Hydrography on the Kara Sea Shelf (Siberia) Depicted in Multiple Single-Valve Analyses of Stable Isotopes in Ostracods," Mar. Geol. 206 (1-4), 147-164 (2004).

32. A. Yu. Stepanova, "Late Pleistocene-Holocene and Recent Ostracoda of the Laptev Sea and Their Importance for Paleoenvironmental Reconstructions," Paleontol. J. 40 (Suppl. 2), 91-204 (2006).

33. A. Stepanova, E. Taldenkova, and H. A. Bauch, "Recent Ostracoda from the Laptev Sea (Arctic Siberia): Species Assemblages and Some Environmental Applications," Marine Micropaleontol. 48 (1-2), 23-48 (2003).

34. A. Stepanova, E. Taldenkova, and H. A. Bauch, "Ostracod Species of the Genus Cytheropteron from Late Pleistocene, Holocene, and Recent Sediments of the Laptev Sea (Arctic Siberia),” Rev. Esp. Micropaleontol. 36 (1), 83-108 (2004).

35. A. Stepanova, E. Taldenkova, J. Simstich, and H. A. Bauch, "Comparison Study of the Modern Ostracod Associations in the Kara and Laptev Seas: Ecological Aspects," Mar. Micropaleontol. 63, 111-142 (2007).

36. I. D. Streletskaya, E. A. Gusev, A. A. Vasil'ev, et al., "New Results of Integrated Studies of the Quaternary Deposits of the Western Taimyr Peninsula," Kriosfera Zemli 11 (3), 14-28 (2007). 
37. F. Swain, "Pleistocene Ostracoda from the Gubik Formation, Arctic Coastal Plain, Alaska," J. Paleontol. 37 (4), 798-834 (1963).

38. E. Taldenkova, H. A. Bauch, A. Stepanova, et al., "Last Postglacial Environmental Evolution of the Laptev Sea Shelf As Reflected in Molluscan, Ostracodal, and Foraminiferal Faunas," Global and Planetary Change 48 (1-3), 223-251 (2005).

39. R. C. Whatley and G. Coles, "The Late Miocene to Quaternary Ostracoda of Leg 94, Deep Sea Drilling Project," Rev. Esp. Micropaleontol. 19 (1), 33-97 (1987).

40. R. C. Whatley and D. G. Masson, "The Ostracod Genus Cytheropteron from the Quaternary and Recent of
Great Britain," Rev. Esp. Micropaleontol. 11 (2), 223-277 (1979).

41. R. C. Whatley, M. Eynon, and A. Moguilevsky, "Recent Ostracoda of the Scoresby Sund Fjord System, East Greenland," Rev. Esp. Micropaleontol. 28 (2), 5-23 (1996).

42. R. C. Whatley, M. Eynon, and A. Moguilevsky, "The Depth Distribution of Ostracoda from the Greenland Sea,” J. Micropaleontol. 17, 15-32 (1998).

43. H. Woszidlo, "Foraminiferen und Ostracoden aus dem marin Elster-Saale-Interglazial in Schleswig-Holstein," Meyniana 12, 65-96 (1962). 